JURNAL BASICEDU

Research \& Learning in Elementary Education

https://jbasic.org/index.php/basicedu

\title{
Elementary School Teachers' Scientific Competence and Their Teaching Experiences
}

\author{
Eka Danti Agustiani ${ }^{1}$, Nuryani Rustaman ${ }^{2}$, Ana Ratna Wulan ${ }^{3}$ \\ Universitas Pendidikan Indonesia, Jawa Barat, Indonesia \\ Email: kadantiani@gmail.com ${ }^{1}, \underline{\text { nuryanirustaman@ upi.edu }}{ }^{2}, \underline{\text { anaratnawulan@gmail.com }^{3}}$
}

\begin{abstract}
Abstrak
Indikator-indikator kompetensi ilmiah dalam literasi sains yang digunakan oleh OECD dalam PISA sejak tahun 2015 adalah (1) menjelaskan fenomena secara ilmiah, (2) merancang dan mengevaluasi penyelidikan secara ilmiah, dan (3) menginterpretasi data dan bukti secara ilmiah. Dalam penerapan kurikulum terintegrasi, guru sekolah dasar juga terlibat dalam pembelajaran sains di tahap awal, yang berarti juga harus memiliki kompetensi ilmiah dan mampu membina para siswa untuk mencapainya. Kajian ini bertujuan untuk mencari tahu korelasi antara ketiga indikator kompetensi ilmiah tersebut dan pengaruh pengalaman mengajar terhadap kompetensi ilmiah guru sekolah dasar. Hasil yang diperoleh mengindikasikan pentingnya pembinaan kompetensi ilmiah pada guru secara periodik dengan memperhatikan semua indikator-indikator kompetensinya.
\end{abstract}

Kata Kunci: guru, kompetensi ilmiah, pengalaman mengajar

\begin{abstract}
The scientific competence indicators in science literacy used by OECD in PISA since year 2015 are (1) describe phenomena scientifically, (2) design and evaluate scientific enquiry, and (3) interpreting data and evidence scientifically. In the application of integrated curriculum, elementary school teachers are also involved in science learning at the beginning, which means they must also mastering the scientific competence and be able to foster their students to achieve it. This study aims to find out the correlation among those three scientific competence indicators and whether the span of teaching experiences of elementary school teachers influenced the competences. The result indicates the importance of fostering teacher scientific competence periodically by taking into account all of the competence's indicators.
\end{abstract}

Keywords: teacher, scientific competence, teaching experiences

@ Jurnal Basicedu 2020

$\triangle$ Corresponding author :

Address : -

Email :-

ISSN 2580-3735 (Media Cetak)

Phone :- 
307 Elementary Scholl Teacher's Scientific Competence and Their Teaching Experiences - Eka Danti Agustiani, Nuryani Rustaman, Ana Ratna Wulan

\section{PENDAHULUAN}

Teachers play important roles in the implementation of the curriculum (DarlingHammond \& Youngs, 2002) as well as elementary school teachers in implementing integrated curriculum which is included science in it. The ideal role of teachers is to guide their students in solving problems and conducting scientific projects, while books and subjects are considered as instruments of the learning process, not as the main source of knowledge (Osborne, 2014). As the first involved teachers in basic science education, the study of elementary school teachers related to their scientific competence's development is still rarely found. It is very important for elementary school teachers to have adequate scientific competence when teaching using scientific approach, so that students succeed in achieving the target of scientific competence as well. Some research related on teachers' scientific competence are mostly about competence of secondary school teachers in conducting inquiry-based science education (Alake-Tuenter et al., 2012; ÇORLU \& ÇORLU, 2012; Jarrett, 1999; Ucar, 2012; Velthuis et al., 2014), scientific attitudes (Murphy \& Smith, 2012; Palmer, 2002; S. I. Van Aalderen-Smeets \& Van Der Molen, 2015), science knowledge (Baker, 1994; Palmer, 2002) and the professional development needs of science teachers or prospective science teachers in general (Rambuda, 2004; Roth \& Roychoudhury, 1993; Spor \& Schneider, 1998)

The aspects of scientific competence which were assessed by Organisation for Economic Cooperation and Development (OECD) in Programme for International Student Assessment (PISA) year 2015 are explain phenomena scientifically, evaluate and design scientific enquiry, and interpret data and evidence scientifically. In science practice, scientific competence is important because of its relationship with the main cognitive abilities such as inductive and deductive reasoning, system thinking, critical decision, information transformation, constructing and communicating argument based on data, thinking in scale model and using science (OECD, 2017). The knowledge about science aspect covering comprehension on main facts and concepts, scientific theory's explanation about nature and technology artefacts, procedure of gaining knowledges, and understand epistemic knowledge. Meanwhile, the aspect of attitude towards science is a set of attitudes that indicate interest in science and technology, science values, appropriate investigation approach, as well as perception and awareness about environmental issues. Therefore, mastery of scientific competence is influenced by the knowledge about science and the attitude towards science (Murphy \& Smith, 2012). For students and adults aged 18 to 70 years, scientific competence can be developed by increasing positive attitudes and involvement with science-related matters, providing more interesting sources of knowledge and science activities, involving them directly in discussions of science topics and increasing self-confidence (Lam et al., 2013).

The aim of this study is to examined the correlation between three scientific competency indicators data obtained of elementary school teachers. The correlation between scientific competency and teaching period of the teachers were revealed as well. The study intended to be the basis of the teacher development recommendations in basic science education.

\section{METHOD}

This paper is analyzing to get the correlation among three indicators of competence of 35 
308 Elementary Scholl Teacher's Scientific Competence and Their Teaching Experiences - Eka Danti Agustiani, Nuryani Rustaman, Ana Ratna Wulan

elementary school teachers who are in charge in upper level class (grade 4 to grade 6). Range of teaching experience of subject teachers are varies which then grouped into 8 months to 11 years $(16$ persons) and 12 years to 36 years (19 persons) teaching experiences. Two of them hold master degree and others are bachelor degree from various subject. The data obtained from written problem set which given to the teachers without prior notice or debriefing, but only equipped with guidance to do the test. This is important since we wanted to identify the real up to dated data of competence' profile, without any initial treatment.

The written problem set consist of three items in essay format to challenge the teachers perform the scientific indicators; (1) making a concept map based on a provided text, (2) design and evaluate a simple science enquiry and (3) interpreting tables of data. Making of a concept map used to examine the scientific competence's aspect of teachers in explaining phenomena scientifically. Concept maps are valuable tools for visualizing information in the mind and they provide gateways to meaningful learning (Dogusoy-Taylan \& Cagiltay, 2014). The categories used to assessed the concept map is type Net, Chain and Spoke (Kinchin et al., 2000). To identify the competence's aspect of design scientific enquiry, subject teachers must design an enquiry plan to test a hypothesis. The chosen enquiry plan is simple and possible to be carried out in elementary school, and an alternative variable were also expected to be seen in the design. The competence of interpret data and evidence scientifically was observed by assigning teachers to interpret two data tables which are load of some not directly related information. To examine the correlation of the periods of teaching experience and the three aspects of scientific competence, as well as among the three aspects of scientific competence, the Fisher Exact Probability
Test is used. This method was chosen because the respondent population was less than 40 and some score number of data was repeated (Agresti, 2007).

\section{RESULT AND DISCUSSION}

The competence's distribution of subject teachers' on three scientific competence indicators and teaching experiences are shown in Table 1. The Fisher Method Exact Probability Test requires each variable only consist of two categories $(2 \times 2$ table forms), therefore, before testing, the categories of each competence aspect are regrouped as shown in Table 1. Correlation test was conducted in $95 \%$ confidence interval, with Ho is the absence of correlation between variables $(p<$ 0.05). By one direct Fisher Exact Test, correlation among the three scientific competence's indicators in pairs and with duration of teaching experience are detected, since all the $\mathrm{p}$ value are $>0,05$ in trust interval 95\% (Table 2).

The highest to the lowest $\mathrm{p}$ value correlation among competence's indicators in pairs respectively are 0,43 for design and evaluate scientific enquiry with interpreting data scientifically; 0,31 for making concept map with interpreting data scientifically; and 0,22 for making concept map with design scientific enquiry. It means that those scientific competence indicators are related and interplay each other in pairs. Therefore, any effort to improve each scientific competence's indicator expected to improve other indicators. Conversely, the weakness in one of scientific competence's indicator will also be related to the weakness of other indicators. The correlation between all of competence's indicator with duration of teaching experience also exist in range $\mathrm{p}$ value $0,20-0,22$.

The most tight correlation found in this study is the ability to design and evaluate scientific enquiry with the ability to interpreting data 
309 Elementary Scholl Teacher's Scientific Competence and Their Teaching Experiences - Eka Danti Agustiani, Nuryani Rustaman, Ana Ratna Wulan

scientifically. Interpreting data and conducting enquiry are included integrated science process skills category, viz the combination of several fundamental science process skills (Roth \& Roychoudhury, 1993). Integrated science skills are important in the process of problem solving or conducting scientific enquiry (Rambuda, 2004). Designing and evaluating scientific enquiry requires creativity. Lin et al. (2013) found a phenomenon that by encouraging students to practice the technique of digging and interpreting data, creativity in making decisions increased rapidly. This result is suspected because the process in handling data is a vehicle for adaptive learning that encourages creativity. Bowen \& Roth (2005) emphasized the importance of data and graph interpretation experiences for pre service teachers to fostering their scientific skills in scientific investigation. They convinced that the ability of interpreting data scientifically also one of basic competence needed to explain phenomena scientifically.

Table 1 Distribution of Teachers Scientific Competence Indicator' Scores

\begin{tabular}{|l|c|}
\hline Competence's indicators & $\begin{array}{c}\text { Percentage } \\
\text { of } \\
\text { Teachers }\end{array}$ \\
\hline Type of Concept Map \\
None \& Spoke (Poor) \\
Chain \& Net (Good) \\
Designing and Evaluating & $26 \%$ \\
Scientific Enquiry & $74 \%$ \\
Score 0 to 2 (Poor) & \\
Score 3 and 4 (Good) & \\
Interpreting Data & $89 \%$ \\
Scientifically & $11 \%$ \\
Score 1 to 3 (Fair) & \\
Score 4 and 5 (Good) & $69 \%$ \\
Teaching Experiences & $31 \%$ \\
$<1$ to 11 years & \\
12 to 36 years & $46 \%$ \\
\hline
\end{tabular}

Table 2 Correlation among scientific competence's indicators and with teaching experience

\begin{tabular}{|l|c|c|}
\hline \multicolumn{1}{|c|}{ Correlation form } & $\begin{array}{c}\text { p } \\
\text { value }^{*}\end{array}$ & Assumption \\
\hline $\begin{array}{l}\text { Design Scientific Enquiry } \\
\text { Scientifically }\end{array}$ & 0,43 & correlated \\
\hline $\begin{array}{l}\text { Make Concept Map with } \\
\text { Interpret Data Scientifically }\end{array}$ & 0,31 & correlated \\
\hline $\begin{array}{l}\text { Make Concept Map with } \\
\text { Design Scientific Enquiry }\end{array}$ & 0,29 & correlated \\
\hline $\begin{array}{c}\text { Teaching Experience with: } \\
\text { make concept map } \\
\text { design scientific } \\
\text { enquiry }\end{array}$ & 0,22 & \\
interpret data & 0,20 & correlated \\
scientifically & 0,22 & correlated \\
correlated
\end{tabular}

*) $\mathrm{p}$ value $\geq 0,05$ means the correlation is exist

Attitude toward science includes cognitive trust to be aware of the relevance, difficulties and gender equality in science, the choice to enjoy or worry in carrying out science practices, and control of acceptance in the form of selfconfidence to succeed and conformity to the context (S. van Aalderen-Smeets \& Walma van der Molen, 2013). The scientific attitudes covered the introduction of scientific aspects in a phenomenon or science enquiry is also related to insight and science literacy. This is what makes the proportion of scores result will be related to scores in interpreting data scientifically. The existing correlation of make concept map with interpret data scientifically also perceptible in the study of social network analysis, which puts concept maps as data networks (McLinden, 2013). 
310 Elementary Scholl Teacher's Scientific Competence and Their Teaching Experiences - Eka Danti Agustiani, Nuryani Rustaman, Ana Ratna Wulan

Without adequate skills in interpreting data, comprehensive concept maps could not be built. In the other hand, concept map can provide a method to analyse thoughts, highlights issues, dilemmas and pathways for discussion and decision (Jennings, 2012). It means a good concept map can be a useful tool to interpret data scientifically as well.

The evaluation of concept maps revealed consistency among concepts, significant relationships, clarity of ideas and logical relationship between the stages of a research project (Bittencourt et al., 2013). Concept map might be used to facilitate students' learning as feedback concerning strengths and weaknesses in the development of critical thinking can be provided (Mok et al., 2014). Those study's result can be the reason why design scientific enquiry have correlation with skill of making concept maps.

There are only slight differences on average scores between two big group of teaching experiences span (Table 3). The indicator's score differences respectively are 0.31 for Make Concept (Explain Phenomena Scientifically), 0.02 for Design Scientific Enquiry, and 0.28 for Interpret Data Scientifically. The interesting thing is the teachers with longer span of teaching experiences got higher score in Interpret Data Scientifically, while the newer teachers got higher score in Make Concept Map (Explain Phenomena Scientifically). A relative wide span of teaching experiences almost give no effect in ability to design scientific enquiry (the difference of score is only 0.02), which is being an unexpected finding in this case.
Table 3 Scores of three competence's indicators on two groups of teaching experiences

\begin{tabular}{|c|c|c|c|}
\hline $\begin{array}{c}\text { Teaching } \\
\text { experiences }\end{array}$ & $\begin{array}{c}\text { Average } \\
\text { Score of } \\
\text { Make } \\
\text { Concept } \\
\text { Map }\end{array}$ & $\begin{array}{c}\text { Average } \\
\text { Score of } \\
\text { Design } \\
\text { Scientific } \\
\text { Enquiry }\end{array}$ & $\begin{array}{c}\text { Average } \\
\text { Score of } \\
\text { Interpret } \\
\text { Data } \\
\text { Scientifically }\end{array}$ \\
\hline $\begin{array}{c}12 \text { to } 36 \\
\text { years }\end{array}$ & 1.63 & 1.58 & 2.84 \\
\hline $\begin{array}{c}0.8 \text { to } 11 \\
\text { years }\end{array}$ & 1.94 & 1.56 & 2.56 \\
\hline Difference & 0.31 & 0.02 & 0.28 \\
\hline
\end{tabular}

The duration of teaching experience automatically enriched teacher's teaching practices, rapidly or slowly, whether in positive or negative direct. A study found that the longer teaching experience correlated more with high-self efficacy and teacher-centred approach, and less with learning strategies (Fendler \& GlaeserZikuda, 2013). A longitudinal study (Alger, 2009) showed that teachers' conceptions become more complex as their experience increases, whereas newer teachers have a tendency to begin with and aspire to student-centred conceptual metaphors. Other study also suggest investing in professional development that integrates content learning with analysis of student learning and teaching rather than advanced content or teacher meta cognition alone (Heller et al., 2012). This certainly related with the achievement of scientific competence of teachers as proven in this study (Table 2 and 3 ). However, it is apprehensive if the teaching experiences can not enhance teacher's scientific competence. Despite the varies of elementary school teacher's educational background, it is very important to refresh, re trait and recharge teacher periodically to keep their education spirit, to improve their weakness, and to update current development in scientific teaching and learning. In one case of study, teachers who had confidence in 
311 Elementary Scholl Teacher's Scientific Competence and Their Teaching Experiences - Eka Danti Agustiani, Nuryani Rustaman, Ana Ratna Wulan

mastering integrated science process skills and could demonstrate good performance in practical application was still low in the conceptual understanding. Pre-service and in-service teacher trainings which can emphasize conceptual knowledge of integrated science process skills are recommended to improve the understanding, proficiency and flexibility in applying integrated science process skills and lead more meaningful learning (Hafizan et al., 2012) The research by (Palmer et al., 2016) revealed that fruitful science learning from students' perspective is the learning with novelty, relevance and a giving a success feeling. Therefore, teacher must continuing improve their science learning method and contextualize the topics.

All the result strengthen the important of higher order thinking skills (HOTS) as the basic behind scientific competence indicators performance. The correlation among the scientific competence's indicators also means that each of indicators required one or some of the same HOTS components. If the teaching and learning processes, either in teacher's education background or which is implement by teachers in the classroom, do not facilitate HOTS within, the scientific competence will not be performed. According to the reference studies above, the more senior and experienced teachers, the more resistance to get out from their comfortable way in teaching. Once the teachers choose the transmission method or rote-learning in teaching, which is relied on lower order thinking skills, as the best way for them, it tends to be more difficult to develop scientific competence both for teachers them self and the students.

\section{CONCLUSION}

The three indicators of scientific competence that were observed turned out to be related each other in pairs, which meant interplay each other. Achievement of one indicator of scientific competence will affect the achievement of other scientific competence indicators. The correlation among the scientific competence's indicators also means that each of indicators required one or some of the same HOTS components. It must be noted that the capacity of the three basic cognitive process dimensions, which are categorised as lower order thinking skills (remember, understand and apply), certainly influence in HOTS' performances as well.

The three indicators of scientific competence were found have correlation with teacher's duration of teaching experience in almost equal values. That result also strengthen the evidence that all of competence indicators correlated each others. The interesting but disappointing finding is the fact of very little differences of achievement between longer span experienced teachers and the newer teachers. The establishment in chosen comfortable teaching way of experienced teachers might be the most reasonable explain (Alger, 2009; Fendler \& Glaeser-Zikuda, 2013)

Scientific competence is very important and can especially be developed in science-based learning. To foster student scientific competence, teachers must first master these competencies, including elementary school teachers through science-based thematic learning. The findings of this study show that the scientific competencies of elementary school teachers still need to be fostered through various forms of professional development programs, both through formal education for preservice teachers, in-service training, activities in 
the teacher working group and experts assistance.

Moreover, the scientific competence of teachers in higher level school (lower and higher secondary schools) are needed to be investigated as well. All of efforts must be supported by suitable of learning and assessment system both for teachers and students. If the learning and assessment based on HOTS, hence scientific competence can be expected to be developed.

\section{ACKNOWLEDGEMENT}

This research is part of a programme funded by the Office of Planning and Foreign Cooperation (BPKLN) of the Ministry of Education and Culture Republic of Indonesia through the Beasiswa Unggulan scheme.

\section{REFERENCE}

Agresti, A. (2007). An introduction to categorical data analysis. New Jersey:John Wiley \& Sons,.45-48.

Alake-Tuenter, E., Biemans, H. J. A., Tobi, H., Wals, A. E. J., Oosterheert, I., \& Mulder, M. (2012). Inquiry-Based Science Education Competencies of Primary School Teachers: A literature study and critical review of the American National Science Education Standards. International Journal of Science Education, 34(17), 2609-2640. https://doi.org/10.1080/09500693.2012.6690 76

Alger, C. L. (2009). Secondary teachers' conceptual metaphors of teaching and learning: Changes over the career span. Teaching and Teacher Education, 25(5), 743-751.

https://doi.org/10.1016/j.tate.2008.10.004

Baker, R. (1994). Research in Science Education, 1994, 24, 31-40 TEACHING SCIENCE IN PRIMARY SCHOOLS: WHAT KNOWLEDGE DO TEACHERS NEED? Robyn Baker Wellington College of Education. 31-40.

Bittencourt, G. K. G. D., da Nóbrega, M. M. L., Medeiros, A. C. T., \& Furtado, L. G. (2013). [Concept maps of the graduate programme in nursing: experience report]. Revista Gaúcha de Enfermagem / EENFUFRGS, 34(2), 172176.

Bowen, G. M., \& Roth, W. M. (2005). Data and graph interpretation practices among preservice science teachers. Journal of Research in Science Teaching, 42(10), 10631088. https://doi.org/10.1002/tea.20086

ÇORLU, M. A., \& ÇORLU, M. S. (2012). Scientific Inquiry Based Professional Development Models in Teacher Education. Educational Sciences: Theory \{\&\} Practice, 12(1), 514-521. http://search.ebscohost.com/login.aspx?direct $=$ true $\% 7 \mathrm{~B} \& \% 7 \mathrm{Ddb}=\mathrm{a} 9 \mathrm{~h} \% 7 \mathrm{~B} \& \% 7 \mathrm{DAN}=841$ $36140 \% 7 \mathrm{~B} \& \% 7 \mathrm{Dsite}=$ ehostlive $\% 7 \mathrm{~B} \& \% 7 \mathrm{Dscope}=$ site

Darling-Hammond, L., \& Youngs, P. (2002). Defining "Highly Qualified Teachers": What Does "Scientifically-Based Research" Actually Tell Us? Educational Researcher, 31(9), 13-25. https://doi.org/10.3102/0013189X031009013

Dogusoy-Taylan, B., \& Cagiltay, K. (2014). Cognitive analysis of experts' and novices' concept mapping processes: An eye tracking study. Computers in Human Behavior, 36, 82-93.

https://doi.org/10.1016/j.chb.2014.03.036

Fendler, J., \& Glaeser-Zikuda, M. (2013). Teaching experience and the "Shift from teaching to learning." Zeitschrift Für Hochschulentwicklung, $8(3), \quad$ 15-28. http://www.zfhe.at/index.php/zfhe/article/vie w/547

Hafizan, E., Halim, L., \& Meerah, T. S. (2012). Perception, conceptual knowledge and competency level of integrated science process skill towards planning a professional enhancement programme. Sains Malaysiana, 41(7), 921-930.

Heller, J. I., Daehler, K. R., Wong, N., Shinohara, M., \& Miratrix, L. W. (2012). Differential effects of three professional development models on teacher knowledge and student achievement in elementary science. Journal of Research in Science Teaching, 49(3), 333362. https://doi.org/10.1002/tea.21004

Jarrett, O. S. (1999). Science interest and confidence among preservice elementary teachers. Journal of Elementary Science Education, $\quad 11(1), \quad 49-59$. https://doi.org/10.1007/bf03173790

Jennings, D. (2012). The Use of Concept Maps for Assessment. UCD Teaching and Learning, May 2012, 1-18.

Kinchin, I. M., Hay, D. B., \& Adams, A. (2000). How a qualitative approach to concept map analysis can be used to aid learning by illustrating patterns of conceptual development. Educational Research, 42(1), 43-57.

https://doi.org/10.1080/001318800363908

Lam, C. C., Alviar-Martin, T., Adler, S. A., \& 
313 Elementary Scholl Teacher's Scientific Competence and Their Teaching Experiences - Eka Danti Agustiani, Nuryani Rustaman, Ana Ratna Wulan

Sim, J. B. Y. (2013). Curriculum integration in Singapore: Teachers' perspectives and practice. Teaching and Teacher Education, 31(1), 23-34. https://doi.org/10.1016/j.tate.2012.11.004

Lin, C. F., Yeh, Y. C., Hung, Y. H., \& Chang, R. I. (2013). Data mining for providing a personalized learning path in creativity: An application of decision trees. Computers and Education, 68, 199-210. https://doi.org/10.1016/j.compedu.2013.05.0 09

McLinden, D. (2013). Concept maps as network data: Analysis of a concept map using the methods of social network analysis. Evaluation and Program Planning, 36(1), 40-48.

https://doi.org/10.1016/j.evalprogplan.2012.0 5.001

Mok, C. K. F., Whitehill, T. L., \& Dodd, B. J. (2014). Concept map analysis in the assessment of speech-language pathology students' learning in a problem-based learning curriculum: A longitudinal study. Clinical Linguistics and Phonetics, 28(1-2), 83-101.

https://doi.org/10.3109/02699206.2013.8078 80

Murphy, C., \& Smith, G. (2012). The impact of a curriculum course on pre-service primary teachers' science content knowledge and attitudes towards teaching science. Irish Educational Studies, 31(1), 77-95. https://doi.org/10.1080/03323315.2011.6340 61

OECD. (2017). PISA 2015 Assessment and Analytical Framework: Science, Reading, Mathematic, Financial Literacy and Collaborative Problem Solving. https://doi.org/10.1787/9789264281820-en.

Osborne, J. (2014). Teaching Scientific Practices: Meeting the Challenge of Change. Journal of Science Teacher Education, 25(2), 177-196. https://doi.org/10.1007/s10972-014-9384-1

Palmer, D. H. (2002). Factors Contributing to Attitude Exchange Amongst Preservice Elementary Teachers. Science Education, 86(1), 122-138. https://doi.org/10.1002/sce.10007

Palmer, D. H., Dixon, J., \& Archer, J. (2016). Identifying Underlying Causes of Situational Interest in a Science Course for Preservice Elementary Teachers. Science Education, 100(6), 1039-1061. https://doi.org/10.1002/sce.21244

Rambuda, A. M. (2004). Perceptions of teachers of the application of science process skills in the teaching of Geography in secondary schools in the Free State province. South African
Journal of Education, 24(1), 10-17.

Roth, W. -M, \& Roychoudhury, A. (1993). The development of science process skills in authentic contexts. Journal of Research in Science Teaching, 30(2), 127-152. https://doi.org/10.1002/tea.3660300203

Spor, M. W., \& Schneider, B. K. (1998). Content reading strategies: What teachers know, use, and want to learn. Reading Research and Instruction, 38(3), 221-231. https://doi.org/10.1080/19388079909558291

Ucar, S. (2012). How Do Pre-Service Science Teachers' Views on Science, Scientists, and Science Teaching Change Over Time in a Science Teacher Training Program? Journal of Science Education and Technology, 21(2), 255-266. https://doi.org/10.1007/s10956011-9311-6

Van Aalderen-Smeets, S. I., \& Van Der Molen, J. H. W. (2015). Improving primary teachers' attitudes toward science by attitude-focused professional development. Journal of Research in Science Teaching, 52(5), 710 734. https://doi.org/10.1002/tea.21218

van Aalderen-Smeets, S., \& Walma van der Molen, J. (2013). Measuring Primary Teachers' Attitudes Toward Teaching Science: Development of the Dimensions of Attitude Toward Science (DAS) Instrument. International Journal of Science Education, 35(4), 577-600. https://doi.org/10.1080/09500693.2012.7555 76

Velthuis, C., Fisser, P., \& Pieters, J. (2014). Teacher Training and Pre-service Primary Teachers' Self-Efficacy for Science Teaching. Journal of Science Teacher Education, 25(4), 445-464. https://doi.org/10.1007/s10972-013-9363-y 